\title{
OVERSOWN TUSSOCK COUNTRY:LESSONS FROM 30 YEARS OF IMPROVEMENT AND MANAGEMENT ON TARA HILLS
}

B.E. ALLAN and H.M. CHAPMAN

Tara Hills High Country Research Station, MAF, Omarama

Abstract

The traditional mix Of white, red and alsike clovers with cocksfoot, ryegrass and timothy was used to improve approximately 2000 ha on Tara Hills High Country Research Station during the 1950s and 1960s. The present frequency of these species, as well as the adventives sweet vernal and browntop, were recorded over contrasting altitude (low, $500-750 \mathrm{~m}$ vs high, $750-1000$ $\mathrm{m})$, aspect (sunny verses shady) and grazing management (controlled versus uncontrolled utilisation).

White clover was the most successful of the oversown clovers, and was most abundant on the moist shady faces. Red clover did not persist on landscapes where utilisation was controlled. Alsike displayed similar landscape and management preferences to red clover. There is a need for a legume that will persist under well utilised low, sunny landscapes. Cocksfoot dominated landscapes where utilisation was uncontrolled, except for high shady faces where browntop was dominant. With controlled utilisation, the frequency of cocksfoot was reduced considerably. Ryegrass was the only introduced grass to show greater frequency under controlled utilisation. The presence of timothy was insignificant on all landscapes. Sweet vernal dispalyed similar tolerances of environment and management to cocksfoot.

Keywords: pasture species, landscapes, aspect, altitude, pasture utilisation.

\section{INTRODUCTION}

Oversowing dominates South Island high country land improvement. Most of this improvement has been achieved using a seed mix of traditional pasture species which has generally included red, white and alsike clovers, and sometimes cocksfoot and ryegrass. This mix is still widely used despite clear evidence that the performance of individual species varies greatly according to temperature, moisture, fertility and management (Scott et al. 1985). While the climatic and nutrient tolerances of species used in high country oversowing are generally appreciated, there is limited information on the additional long-term effects of grazing management on such species (Allan 1985).

The traditional oversowing seed mix was used extensively to help revegetate and improve a variety of hill landscapes at Tara Hills High Country Research Station during the 1950s and 1960s. By looking at what is thriving on different aspects, at different altitudes, and under different managements today, lessons such as where on a run pasture species perform best, and where they are not worth oversowing can be learnt.

\section{MATERIALS AND METHODS}

Eight landscape units (sites) on Tara Hills Research Station (mean rainfall 520 $\mathrm{mm}$ ), were chosen to represent a factorial combination of contrasts in altitude (low $=500-750 \mathrm{~m}$; high $=750-1000 \mathrm{~m}$ ), aspect (sunny-predominantly northern aspect; shady-predominantly southern aspect), and history of pasture management (controlled verses uncontrolled utilisation).

All sites were oversown between 1950 and 1968 with the following mix: red clover (Trifolium pratense) 2, white clover (T. repens) 2, alsike clover (T. hybridum) 2, cocksfoot (Dactylis glomerata) 2, ryegrass (Lolium perenne) 5, and timothy (Phleum pratense) $2 \mathrm{~kg} / \mathrm{ha}$. Specific cultivars were not recorded. No ryegrass was sown on site 3 and lucerne (Medicago sativa) was included in the mix on site 1 (Table 1). 
Table 1: The percentage frequency of pasture species on landscapes at Tara Hills. ( ) Site number. $\mathrm{C}=$ Controlled utilisation, $\mathrm{U}=$ Uncontrolled utilisation.

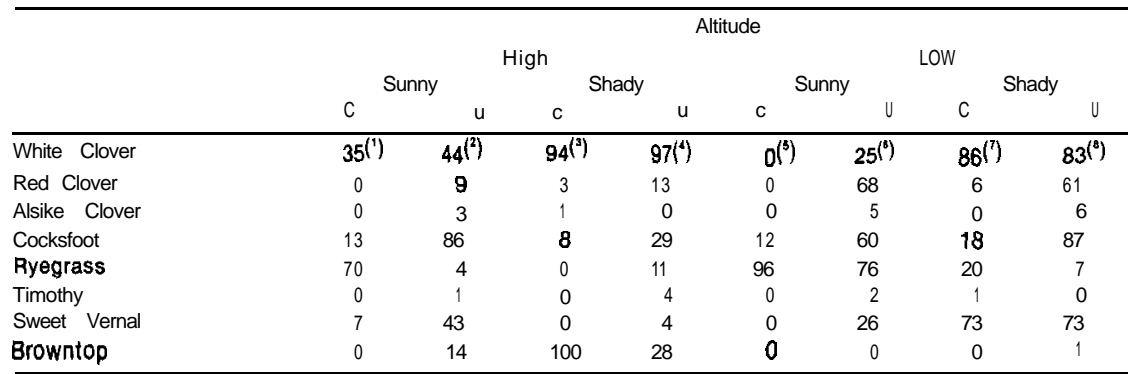

Table 2: Variation in species frequency under the contrasting effects of altitude, aspect and management. $P<0.01$

\begin{tabular}{|c|c|c|c|c|c|c|}
\hline \multirow[t]{2}{*}{ Species } & \multicolumn{2}{|c|}{ Altitude } & \multicolumn{2}{|r|}{ Aspect } & \multicolumn{2}{|c|}{ Utilisation } \\
\hline & High & LOW & Sunny & Shady & Controlled & Uncontrolled \\
\hline White Clover & 270 & 194 & 104 & $360^{\prime}$ & 215 & 249 \\
\hline Red Clover & 25 & $135^{\prime}$ & 77 & 83 & 9 & $151^{*}$ \\
\hline Alsike Clover & 4 & 11 & 8 & 7 & 1 & 14 \\
\hline \multirow[t]{2}{*}{ Cocksfoot } & 99 & 105 & 171 & 142 & 51 & $262^{\prime}$ \\
\hline & & & (high & sunny/low shady & $36: 177)^{*}$ & \\
\hline Ryegrass & 85 & 199 & 246 & $36^{\prime}$ & 166 & $98^{\prime}$ \\
\hline Timothy & 5 & 3 & 5 & 3 & 1 & 7 \\
\hline Sweet vernal & 54 & $172^{\prime}$ & 76 & $150^{\prime}$ & 80 & $146^{\prime}$ \\
\hline Browntop & 142 & $1^{*}$ & 14 & 129 & 100 & $43^{\prime}$ \\
\hline
\end{tabular}

Since improvement, these areas have received regular maintenance fertiliser, approximately $125 \mathrm{~kg}$ Sulphur super/ha every two years, and have been grazed at 1.5-2.0 su/ha/year. Considerable subdivision fencing has been undertaken to improve grazing control. The utilisation of a site was considered 'uncontrolled' when the block in which it was located contained contrasting aspect and/or altitude classes. Likewise, the utilisation of a site was 'controlled' when the block in which it was located did not have contrasting aspect and altitude, and therefore could receive a specific management. Pasture utilisation within "controlled" blocks was generally greater and more even that that within "uncontrolled" blocks.

On each site four transects were located at $45^{\circ}$ to the slope. A $20 \mathrm{~cm}$ diameter ring was placed at $1 \mathrm{~m}$ intervals 25 times along each transect, and presence of all the oversown plant species and the adventive grasses, sweet vernal (Anthoxanthum odoratum) and browntop (Agrostis capillaris), rooted inside the ring was recorded. Percentage frequency of species was calculated as their total number of occurrences on any one site.

The main effects of altitude, aspect and management, and the first order interactions between these were investigated using a generalised linear model (McCullagh \& Nelder 1983).

\section{RESULTS}

White clover was the most abundant clover over all sites (Table 1). Presence was most influenced by aspect, with greater frequency on shady than sunny faces (Table 2). Management appeared to have little influence, although low/sunny/controlled utilisation was the only site where white clover was absent. Presence of red clover was greatest on the low sites with uncontrolled utilisation. There was no significant difference between aspects. Occurrenceof alsike was insignificant compared to that 
of the other introduced clovers. However, trends were similar to that for red clover, with greater occurrence under uncontrolled than controlled utilisation.

Presence of cocksfoot was greater under uncontrolled than controlled utilisation (Table 2). A strong interaction between aspect and altitude was evident in cocksfoot frequency, with greater presence on sunny faces at high altitudes, and on shady faces at low altitudes. There was more ryegrass on sunny than shady aspects. Frequency was also greater on low than high altitudes, and for controlled than uncontrolled utilisation.

Although oversown on all sites, occurrence of timothy was insignificant in relation to that of cocksfoot and ryegrass (Table 2).

Trends in the frequency of sweet vernal were similar to those for cocksfoot (Table 1). Presence was greater under uncontrolled than controlled utilisation and while differences were not fully explained by the altitude $x$ aspect interaction, there appeared to be more sweet vernal on low/shady and high/sunny faces. Browntop was almost entirely associated with the high/shady/controlled utilisation site where $100 \%$ frequency was recorded. There was virtually no occurrence of browntop at low altitudes.

\section{DISCUSSION}

The sites recorded in this study are typical of the range in oversown landscapes encountered in the dry inter-montane areas of the South Island. The following discussion and conclusions are considered relevant to those areas.

\section{Clovers}

White clover is clearly the most successful of the oversown clovers. The influence of aspect and altitude on white clover appears to be a common effect of summer soil moisture levels, that is less clover where there is greater moisture stress. Summer soil moistures are greater on shady aspects and at higher altitudes, but in the 500-1000 m altitude zone, aspect has the greatest influence (Tara Hills unpub. data). Thus it is not surprising that white clover was most frequent on shady aspects (Figure 1). At Tara Hills grazing research relevant to high/shady landscapes as defined in this paper has shown management has little influence on white clover cover (Allan 1985). The data presented here supports this, and shows the same thesis applies to high/sunny and low/shady landscapes. However, when moisture stress is combined with controlled utilisation (ie site 5), white clover will not persist.

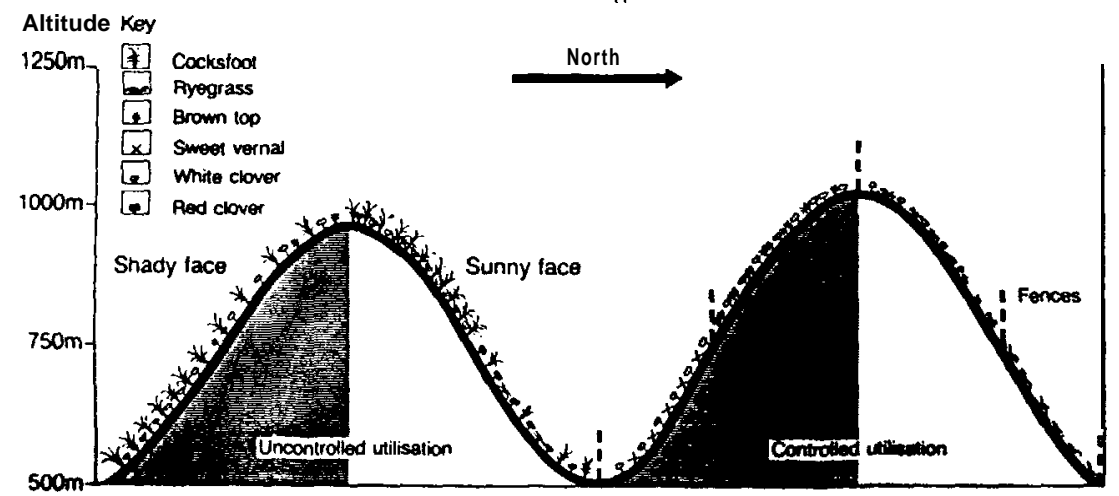

Figure 1: A hypothetical hill pasture profile for Tara Hills, showing the dominant species on low and high, and sunny and shady landscapes under both controlled and uncontrolled utilisation. 
Red clover may establish and produce well on low sunny landscapes (Rhodes and Clare 1983). By the mid 1960s there was more red than white clover on the low sites examined in this study (Tara Hills unpub. data). But where pasture utilisation has been controlled, red clover has not persisted. Clearly, if efficient utilisation of oversown country is a primary objective, then inclusion of red clover in the seed mix for that block would be a waste of money. Work is now underway at Tara Hills to find a suitable legume that will persist under well utilised low/sunny landscapes (Keoghan 1986).

While alsike clover is well known for good establishment and initial vigour (Keoghan 1986), there is growing concern over its lack of persistence. In this study, alsike responds to environment and management in a similar way to red clover, and should therefore be regarded as a companion, rather than a substitute for white clover.

\section{Grasses}

Tara Hills now carries ten times the stock units it did in 1950. This increase is largely attributable to cocksfoot, in particular its ability to provide grazing through the winter months. By the mid 1960s, the low altitude landscape on Tara Hills, that prior to 1950 was very sparsely covered with scabweed and native grasses, was dominated by cocksfoot (Tara Hills unpub. data). But where utilisation has been controlled, there is now considerably less cocksfoot. A similar response occurred on the Tara Hills grazing trial (Allan 1986), where it was found that this loss of cocksfoot associated with improved pasture utilisation could be reduced considerably if an adequate spell from grazing was achieved through rotational grazing. Grasslands Wana cocksfoot is an alternative to the traditional Apanui, as it is more persistant under continuous stocking (Lancashire \& Brock 1983). Wana is presently under grazing evaluation at Tara Hills.

Ryegrass was the only introduced species to display an increase in frequency associated with controlled utilisation. This response was consistant for all aspects and altitudes except high/shady where for one block (site 3) ryegrass was never oversown. New Zealand bred ryegrasses will not tolerate very cold landscapes (Allan 1985) and therefore have limited application on high/shady sites. More cold tolerant ryegrasses of European origin are now under grazing evaluation at Tara Hills. Ryegrass seed is seldom included in high country oversowing seed mixes (Scales et al. 1975) probably because the species is not successful under uncontrolled utilisation and is considered inferior in its ability to carry well into the winter. But recent evidence shows ryegrass quality does not deteriorate greatly when frosted (Daly \& Allan 1985, Scott \& Maunsell 1986), and the authors feel that if a good level of utilisation (eg $60-70 \%$ ) is intended, then ryegrass must be included in the oversowing mix.

This study has highlighted the complementarity between cocksfoot, ryegrass and browntop in terms of environment and grazing management. On landscapes dominated by browntop (eg site 3 ) there appears little point in the traditional approach of cocksfoot and ryegrass introduction. This conclusion is supported by Hall (in this volume). For other landscapes, cocksfoot can be successfully established and if laxly grazed may eventually become the dominant species. If pasture utilisation is improved, contribution from cocksfoot will decrease, but this can be offset by introduction of ryegrass (Figure 1).

The adventive sweet vernal, often referred to as 'poorman's cocksfoot', has similar tolerances of environment and management as does cocksfoot. Relative to the other grasses discussed here, sweet vernal is quick to set seed following close grazing and, with its adventive nature, the grass will dominate well utilised 
rotationally grazed blocks where cocksfoot and ryegrass have not been successfully introduced.

Timothy has not persisted on any of the landscapes on which it was oversown at Tara Hills.

\section{CONCLUSIONS}

When choosing species to oversow landscapes in the dry intermontane areas of the South Island (eg around $500 \mathrm{~mm}$ rainfall, 500-1000 $\mathrm{m}$ altitude) the following should be noted:

1. White clover is unlikely to persist on well utilised sunny faces below $750 \mathrm{~m}$. Here an alternative legume such as birdsfoot trefoil (Lotus corniculatus) or lucerne should be considered.

2. Red and alsike clover will not persist as well as white on blocks that are well utilised. Alsike should be regarded as a companion rather than a substitute for white clover.

3. Cocksfoot can tolerate a large range of environments, and will in time become the dominant species under lax grazing.

4. Ryegrass will respond to improved utilisation, especially on the more fertile soils below $750 \mathrm{~m}$. Here ryegrass should be given greater priority than cocksfoot in the seed mix.

Acknowledgements
R.J. Doney for technical assistance, and P.D. Johnstone for statistical advice

References

Allan B.E. 1965. Grazing effects on pasture and animal production from oversown tussock grassland. Proceedings NZ Grassland Association 46: 119-125.

Allan B.E. 1986. Pasture species most suited to non-arable hill and high country. A new look at traditional species. Proceedings 1985 Hill and High Country Seminar, Centre for Resource Management, Lincoln College, 39.44.

Daly M.J., Allan B.E. 1985. Autumn saved pasture in a high frost environment. Proceedings NZ Grassland Association 46: 135.140 .

Keoghan J.M. 1966. Fitting pasture species and cultivars into high country land- scapes and grazing systems. Proceedings 1985 Hill and High Country Seminar, Centre for Resource Management, Lincoln College, 29.30.

Lancashire J.A., Brock J.L. 1983. Management of new cultivars for dryland. Proceedings NZ Grassland Association 44: 61.73.

McCullagh P., Nelder J.A. 1963. Generalized Linear Models. Chapman and Hall.

Rhodes P.J., Clare R.C. 1963. Legume oversowing on hill country in Marlborough. Proceedings NZ Grassland Association 44: 142.148.

Scales G.H., Currie J.O., Lissick K.P., Donaldson T.H. 1975. Tara Hills High Country Survey 1973. Tussock Grasslands and Mountain Lands Institute Review 31: 31.43.

Scott D., Keoghan J.M., Cossens G.G., Maunsell L.A., Floate M.J.S., Wills B.J. Douglas G. 1965. Limitations to pasture production and choice of species. Chapter 1. In: Burgess R.E., Brock J.L. (Ed). Using herbage cultivars. Grassland Research and Practice Series No. 3. NZ Grassland Association.

Scott D., Maunsell L.A. 1986. Winter feed quality of some grasses in the high country. NZ Journal Experimental Agriculture 74: 19.24 